\title{
Construction labor and skill shortages in Croatia: causes and response strategies
}

DOI 10.2478/otmcj-2020-0019

Received March 30, 2020; Accepted April 20, 2020

\begin{abstract}
The construction labor is crucial to the construction industry, which is known globally for its creation of jobs at different skill and professional levels. The world's construction industry is currently experiencing a rapid recovery after the 2008 global crisis. This positive growth is also noticeable in Croatia. Nevertheless, the industry is experiencing a considerable shortage of skilled labor. First, this paper investigates the main causes of the current condition of the labor market through an extensive literature review and construction market analysis. Second, the case study of the Croatian construction labor market is presented. The longitudinal study of official statistical data shows that the total number of workers employed over the last 10 years has decreased significantly. There has been an increase in the number of unskilled workers and a decrease in the number of all other types of workers between 2016 and 2017. Following the literature review and market analysis, the response strategies for the problem of labor shortage in Croatian construction are provided and discussed.
\end{abstract}

Keywords: construction labor, labor shortage, skill shortage, Croatian construction industry, Croatian labor market

\section{Introduction}

A decade after the financial crisis of 2008, the construction industry is experiencing a global recovery. The production value in construction has been rising continuously since 2013 in the European Union (EU) (Eurostat 2019). The USA is also showing a positive rate since 2014 (US Census Bureau 2018). In China, the total nationwide investment in fixed assets has doubled in the period 2008-2013 (EU SME

\footnotetext{
*Corresponding author: Ivona Ivic, Faculty of Civil Engineering, University of Zagreb, Zagreb, Croatia, E-mail: iivic@grad.hr Anita Ceric, Faculty of Civil Engineering, University of Zagreb, Zagreb, Croatia
}

Centre 2015). As the world's construction industry experiences a rapid recovery after the financial crisis of 2008, there is a need for a large number of manual workers, both skilled and unskilled. On the other hand, the construction industry is currently experiencing a considerable shortage of skilled labor. Recent studies regarding this subject have emphasized labor shortage as a global issue. Han et al. (2008) suggest that the problem is rooted in the sector's poor image, unclear career paths, lack of training and education, declining wages, and poor work environment. There is also the problem of an aging workforce. The characteristics of the construction industry simply do not appeal to young, potentially qualified manpower.

The research in the construction management field has uncovered the shortage of skilled labor as the major problem in the global construction labor market. The consequences of the shortage of skilled labor include poor quality of project performance and higher costs (Karimi et al. 2018). Among the reasons for increased costs are the expenses concerning recruitment, training, and retaining the labor force in the construction industry (Han et al. 2008). Other reasons include the tendency of unskilled workers to deliver poor quality and low productivity, which results in late project completion (Abiola 2004; Bilau et al. 2015).

According to the results of an industry-wide survey released by Autodesk and the Associated General Contractors of America (AGC of America, 2018), 80\% of construction firms report that they are having a hard time filling hourly craft positions that represent the bulk of the construction workforce. Association officials in that report state that shortages pose a significant risk to future economic growth. In another report, analyzing the productivity change across Europe and the USA, Farmer (2016) concludes that the shortage of construction workers is a global problem.

In this paper, the problem of skilled labor shortage is discussed. An analysis of the workforce in the construction industry across the globe is presented. Next, this problem is investigated in the case of Croatia. Concerning the labor and skill shortages in Croatia, this paper analyzes data 
collected from the Croatian Central Bureau of Statistics. Furthermore, existing response strategies in Croatia are investigated. Finally, the discussion of possible response strategies is provided based on data collected from the literature.

\section{Problem identification and research objective}

In Croatia, the recovery of construction sector started later in comparison to that in other European countries. According to the data of the Croatian Central Bureau of Statistics (2018a), after 2015, volume indices of construction work have started to increase. However, researchers have been warning about the consequences of global growth since the last construction boom before the crisis of 2008 . MacKenzie et al. (2000) and Dainty et al. (2004) mention that as a result of the growth, the industry is expected to experience considerable skill shortage. Today, this problem is prevalent and growing.

Several reports dealing with world employment have indicated that labor shortages present a threat for the future. Thus, the International Labor Organization (2020) presents the newest data on the aging labor force, together with labor shortages and skill mismatches in Europe, Central Asia, and North America. This problem is also addressed in the report of the European Commission (2015), which emphasizes the need for labor migration in the EU member states. Labor shortages are taken very seriously in the EU member states, and they are continuously working on the aggregation of data about shortages in specific sectors. Shortages in the construction industry are particularly emphasized in Finland, France, Poland, Luxembourg, Latvia, Belgium, Malta, Slovenia, and Sweden (European Commission 2015). Another report on the EU construction industry (European Commission 2017) has indicated an increase in vacancies by $0.2 \%$ over the 2009-2015 period, the mismatch between the supply and demand of labor, and a considerable skill shortage.

The main objective of this paper is to highlight the problem of labor and skill shortages in the construction industry. Therefore, an extensive literature review is conducted to capture the answers for the first two research questions that follow:

1. What are the main causes of labor and skill shortages in the construction industry across the world?

2. What are the response strategies identified by other researchers across the globe?
Next, the case study of Croatia is selected to investigate the causes of and response strategies to alleviate construction labor and skill shortages. The case is intended to answer the following research questions:

3. What are the main causes of labor and skill shortages in Croatia?

4. What is the magnitude of these shortages?

5. What are the existing measures used to mitigate the current crisis in the construction labor market in Croatia?

6. Which new response strategies could be implemented in Croatia to mitigate the current crisis in the construction labor market?

This paper attempts to provide answers to these research questions, which will be addressed in the order in which they appear above.

\section{Literature review}

Olsen et al. (2012) argue that a skill shortage occurs when the demand for workers for a particular occupation is greater than the supply of personnel who are qualified, available, and willing to work under existing market conditions.

Chini et al. (1999) describe skilled craftspeople by their reliance on their mechanical skills and their emphasis on production. They also claim that there is no other individual on any given site that possesses a more specialized and complete understanding of a trade than the skilled craftsperson. Craftspeople typically have some type of formal training in their crafts and have been working in the field for many years. In addition, Bilau et al. (2015) claim that craftspeople in the construction sector play an essential role in the survival and development of the sector as they are directly involved in construction operations. This can be explained by the fact that when qualified skilled craftspeople are involved in some action, it tends to eliminate the concern for poor quality, low productivity, and late project completion by reducing rework (Bilau et al. 2015). Furthermore, projects facing skilled labor shortages have higher cost overruns compared with projects that do not (Karimi et al. 2018). Research papers have identified skilled labor shortage as a serious problem for the construction industry in several countries across the world. Different causes for this labor market crisis have been identified, and they all lie in the characteristics of the construction sector, which are explained hereunder. 


\subsection{Causes of shortages}

Human resources are essential to the construction industry. As claimed by Dainty et al. (2007, p. 3), the "construction industry is one of the largest, complex and most people-intensive sectors". On the other hand, most of the construction companies are known for poor human resource management (HRM). This is mainly because of the sector's highly fragmented nature, dominated by small firms (Dainty et al. 2007). In fact, small firms generally do not have HRM practices. There is also a high rate of subcontracting, which has some adverse consequences for workers, companies, the industry, and HRM functions (Debrah and Ofori 1997). The consequences of such an approach are inadequate employment practices, unclear career path for construction workers, lack of training and education, and poor work environment (Dainty et al. 2007). In this regard, Ford and MacKenzie (2007) have investigated high levels of contingent labor in the construction industry and pointed out that, regardless of the contractual form used, labor shortages have driven a reliance on outsourcing and self-employment within the sector, which has in turn led to further casualization of the employment relationship. The problem is that the contingent labor does not offer a basis for maintaining the sector's long-term skill profile (Ford and MacKenzie 2007). In fact, Raiden et al. (2007) claim that this type of employment leads to the low-cost, low-skill, and low-productivity culture that pervades the industry.

Other characteristics of the construction industry also influence its poor image among workers. Some of these characteristics are cyclical demand, structural flexibility of the construction sector, construction being mainly a project-based industry, and the workforce diversity (Dainty et al. 2007). Furthermore, some studies (Fiori 2003; Oseghale et al. 2015) show that skilled construction workers are unwilling to recommend the profession to their children. In fact, in a survey of high school students by the National Business Employment Weekly, the "Construction Worker" category came in at No. 247, out of a possible 250, as an attractive career option (Kashiwagi and Massner 2002). Oseghale et al. (2015) also find that the entry of young people into the construction trades is very low, which results in the problem of the aging workforce in the construction sector. Finally, Kim et al. (2020), in a most recent paper, reveal that there are four major causes for the shortage of skilled labor in the construction industry: (1) training and education for skilled labor; (2) poor image of the construction industry; (3) aging skilled labor; and (4) labor wages.
The problem of labor and skill shortages is, therefore, rooted in the construction sector's characteristics and specific culture.

\subsection{Response strategies}

The solution to the labor and skill shortages is proposed in existing literature through two types of strategies: short term and long term.

\subsubsection{Short-term measures}

Short-term actions are intended as a means to quickly fill vacancies and stabilize the current situation. They are based on retaining those workers currently employed (Chini et al. 1999) and fast filling of vacancies with new-profile labor (Dainty and Bagilhole 2005; Han et al. 2008). On the other hand, long-term strategies are essential for resolving the labor shortage problem. They include changing of the construction education system to develop new interest in the industry, as well as improving the poor image of the construction worker into that of a skilled professional (Chini et al. 1999).

Some of the short-term actions mentioned in the literature include nontraditional recruitment, foreign workers' employment, multiskilling, implementation of skill-matching and labor-sharing programs, contracting less work, and investing in wages and talent management.

Dainty and Bagilhole (2005) promote nontraditional recruitment, which includes employment of women (also see Morello and Issa 2018) and ethnic minorities (also see Lyu et al. 2018), as well as the option of adult (re) training. Nevertheless, Powell and Sang (2013) emphasize that, despite all the efforts, the construction sector remains predominantly white, male, heterosexual, and able-bodied. The other, similar solution for the fast filling of the vacancies in the construction sector is the employment of foreign workers. Han et al. (2008) have investigated the critical issues of poor productivity and communication difficulties caused by different work ethics and cultural customs, which arise in the construction fields, between foreign construction workers and firms that hire them. Nevertheless, with the implementation of potential motivating strategies, foreign workers could replace the missing skilled labor (Han et al. 2008).

Furthermore, multiskilling is a strategy that can address the labor shortage problem by utilizing the existing workers more efficiently. Haas et al. (2001) state 
that multiskilling decreases the number of workers hired for a project and can improve productivity. A multiskilled labor force is essentially one in which the workers possess a range of skills that allow them to participate in more than one work process (Gomar et al. 2002). Gomar et al. (2002) claim that the success of multiskilling lies in a foreman's ability to assign tasks to workers according to their knowledge, capabilities, and experience in former projects. Haas et al. (2001) further argue about the requirement of broader training in multiskilling and the need for changing companies' management systems and structure in order to successfully implement multiskilling in construction. Both papers (Haas et al. 2001; Gomar et al. 2002) investigate possible implementation strategies for multiskilling and present this strategy as a solution for shortage of skilled labor in the construction sector.

Chini et al. (1999) outline the easiest and most basic approach for keeping existing workers happy: using bonuses, overtime opportunities, loyalty rewards, and promotions as incentives. They further analyze the implementation of skill-matching programs (or minimization of skill mismatches while filling the vacancies) and labor-sharing programs, which are used by some contractors and owners to share existing labor and schedule projects together. Chini et al. (1999) also argue that some contractors simply contract less work and, therefore, keep the loyalty of their existing subcontractors. In a recent analysis, Aiyetan and Dillip (2018) similarly propose investments in labor wages, talent management, and staff development programs.

\subsubsection{Long-term measures}

In order to respond to the labor and skill shortage problems over the long term, researchers propose strategies mainly oriented toward education, training of workers, changing the image of the sector, and changing the construction processes.

Researches agree that changes in education (Chini et al. 1999; Kashiwagi and Massner 2002; Wang et al. 2008; Pan et al. 2020) and informal (on-the-job) training by employers (Chini et al. 1999; MacKenzie et al. 2000; Dainty et al. 2004; Olsen et al. 2012; Pan et al. 2020) are essential for mitigating labor shortage. Skill formation trainings are especially emphasized as an enhancement of construction productivity (Debrah and Ofori 2001; McGuinness and Bennett 2006). In their research, Kashiwagi and Massner (2002) have identified necessary changes for undergraduate and graduate education programs. Chini et al. (1999) furthermore emphasize the need of more school-to-work programs at the high school level, where children begin to achieve their individual career goals. In addition, to provide standardized education that satisfies market needs, governments can implement skills certification schemes. Examples are UK's Construction Skill Certification Scheme (MacKenzie et al. 2000) and Germany's tripartite process of defining skills between the state and the social partners, viz., trade unions and employers (Clarke and Herrmann 2007). Furthermore, Dainty et al. (2004) argue that only coordination among the following can bring in results: attracting new entrants into the industry, engaging employers in training, opening up funding streams/training frameworks, and providing labor market planning. Chan and Dainty (2007) also claim that labor shortage should be resolved at three levels: industry level, firm level, and individual level. In other words, cooperation between employers and government, as well as mutual effort of all participants, is needed while addressing this problem. This cooperation and coordination can be given through labor market planning (Dainty et al. 2004). Labor market planning is regionally driven and needs to be established in a particular market. It includes the creation of a single agency to take on the responsibility for collecting, analyzing, and disseminating skills-related data within the region in order for construction firms to plan more effectively for the future (Dainty et al. 2004). This model already exists in Germany, where collective employment relations, institutional structure of learning, and their dual vocational education tend to show good results in skill formation and better productivity on site (Clarke and Herrmann 2007).

Along with education and training, the current poor image of the construction industry should be changed to encourage the entry of new workers on the market (Chini et al. 1999; Fiori 2003). To address this problem, all those involved in the construction business should begin to grow better relations - firm to firm, and firm to employee. HRM practices should be brought to construction companies, and management should treat their workers as people and not as expendable commodities (Chini et al. 1999). Chini et al. (1999) also argue that in terms of accomplishing this improvement, owner participation is needed through financing and employer participation, through more effective training programs as well. Furthermore, Fiori (2003) suggests the implementation of events like Construction Career Fairs, organized to expose high school and college students to the broad array of diverse career opportunities offered within the construction industry. Naturally, similar programs can also be undertaken with the incentive of the industry and the government of a particular country (MacKenzie et al. 2000). 
MacKenzie et al. (2000) also propose redesigning the construction processes in order to minimize the need for labor. The redesign should include the implementation of new technology and construction techniques, along with greater use of prefabrication and the automation of construction sites (MacKenzie et al. 2000).

\section{Methodology}

Labor shortage, being a global problem, needs to be investigated in specific markets, such as the construction labor market in Croatia. Thus, a case study of the Croatian construction labor market is selected to provide insights into the real extent of labor and skill shortages, as well as to discuss possible response strategies depending on the characteristics of a particular country. A case study is appropriate when researchers have little or no control over behavioral events and the focus of the study is a contemporary phenomenon (Yin 2018). Therefore, this research is designed as a single case study of a country and its construction industry labor market, combining quantitative and qualitative data. In this regard, qualitative analysis is used to answer the research questions 3, 5, and 6, while quantitative (statistical) analysis is used to answer the research question 4.

First, the industry background is explored, followed by an analysis of causes of labor shortages in the Croatian construction industry. Then, a longitudinal study of the 2008-2017 period is conducted to see the employment trends. These longitudinal data are the official statistical data of the Croatian Bureau of Statistics (2018a), and they are explored to provide insight into the change of a particular unit (Mills et al. 2010), in this case, the number of employees in the construction industry. The statistical data are used in this case study in order to collect, categorize, analyze, and present the numerical information (Mills et al. 2010, p. 893). First, the trend in the total number of persons employed in the construction sector is analyzed. Second, the trend in the skill level among construction workers is analyzed, looking at the absolute number and the percentage of each skill level among the total number of construction employees. In the latter case, longitudinal data are appropriate to see whether the percentage of persons with the same skill levels stayed the same over the entire period or whether it changed, indicating some adverse events in the labor market. After the quantitative analysis, the existing measures for mitigating labor shortages in Croatia are explored. They are further discussed and complemented with additional measures described in the literature review. Finally, the list of possible response strategies for the Croatian construction industry is established and briefly discussed.

\section{The case of the Croatian construction labor market}

The Croatian construction market has gone through drastic changes in the past decade. After a period of constant growth during the years 1998-2008, the Croatian construction sector experienced a crisis that lasted 6 years (2009-2015). After 2015, the Croatian construction sector once again started to recover. The big "boom" in the Croatian construction sector in the period 2000-2008 resulted in an increase in the gross domestic product (GDP) from $4.2 \%$ to $7.3 \%$, as well as an increase in employment among legal entities by 61.1\% (Djukan et al. 2015). This growth was mainly leveraged by major infrastructure projects such as highways (Djukan et al. 2015). One big change for Croatia in 2013 was its accession to the EU. This encouraged investments in the construction sector as well. The first positive changes began after 2015, when the sector's indicators (volume indices of construction work and the sector's share in GDP) started to grow following the recovery of the EU economy (Croatian Bureau of Statistics 2018a; Buturac 2013-2018). This increase in the volume indices of construction work indicates an increase in demand for construction workers, both skilled and unskilled. In the next two sections, statistical analysis is conducted in order to investigate the current labor market in the construction sector of Croatia.

\subsection{Labor shortage}

As the skilled labor shortage is a global problem, it is expected in Croatia also. In fact, a few years ago, the Croatian Chamber of Civil Engineers expressed its concerns about the construction labor shortage in Croatia and appealed for the implementation of urgent measures for strategic employment in the sector (Djukan et al. 2015). Although it is a well-known issue, as far as the authors are aware, there is no research on labor shortage in Croatia that proposes solutions to this problem. Therefore, this paper provides important data and possible response strategies that Croatian construction companies can use. Analysis of the data collected from the Croatian Bureau of Statistics (2018a) is carried out to show the scale of the problem. The period of analysis is set as 10 years (20082017). It should be noted that data following 2017 are not 
yet available. The trend in the total number of persons employed in the construction sector is depicted in Figure 1. The data show that the Croatian construction industry, at its peak year (2008), employed 145,656 workers. Then, the number of workers decreased drastically by $39 \%$ in the period of crisis, i.e., 2009-2015. The construction market lost 56,925 employees in that period. After 2015, employment started to slowly rise, reaching 93,986 workers in 2017. However, the number of workers who entered the market during the final 2 years $(\mathrm{N}=5,255)$ was not enough to cover all the losses incurred during the period of crisis.

There are various causes for the labor shortage in Croatia. One reason for the decreasing number of educated workers even in the period of the sector's growth can be found in the emigration of the working population (Djukan et al. 2015). Economic and political emigrations started after Croatia's accession to the EU. This enabled young, skilled, and highly educated individuals to find new employment in more-developed countries with better-organized and motivating environments. Croatia had 149,559 emigrants in the 2013-2017 period and only 62,260 immigrants. The total loss of people through emigration amounted to 87,299 in this 4-year period (Croatian Bureau of Statistics 2018a). According to Pokos (2017), the numbers are even more serious because the Croatian Bureau of Statistics counts only emigrants who have officially "signed out" their residence in Croatia; but, in reality, people leave the country more often without that legal step. The working population (20-64 years old) constituted 74\% of the total number of emigrants in 2017 (Croatian Bureau of Statistics 2018b). However, emigration, in general, is only triggered by a lack of satisfactory working conditions in Croatia. The construction sector is especially unappealing for potential employees. With its average monthly pay of $19 \%$ below the country's average (Croatian Bureau of Statistics 2018a), the general poor image caused by corruption (Glavinja et al.2017), a culture of clans, a hierarchy rather than a market, adhocracy orientation (Sandrk Nukic and Huemann 2016), and inadequate HRM, the Croatian construction sector is having a hard time attracting new skilled and educated employees.

\subsection{Skill shortage}

The Croatian construction workforce is divided into unskilled, semiskilled, skilled, and highly skilled employees with basic school and secondary school education, nonuniversity college degrees, and university degrees (Croatian Bureau of Statistics 2018a; data for the years 2008-2017). Unskilled workers are those without any formal or informal education in construction. Semiskilled workers are unskilled workers who have completed some short educational course in construction. Skilled workers are those with high school education of 3 years. Highly skilled workers are those who have also passed craft-specific examinations in their field of work. Workers with secondary school degrees are those who have completed some kind of high school program of 4 years. Other terms, namely, employees with basic school education, nonuniversity college degrees, and university degrees, are self-explanatory.

According to data from the Croatian Bureau of Statistics (2018a; data for the years 2008-2017), the number of

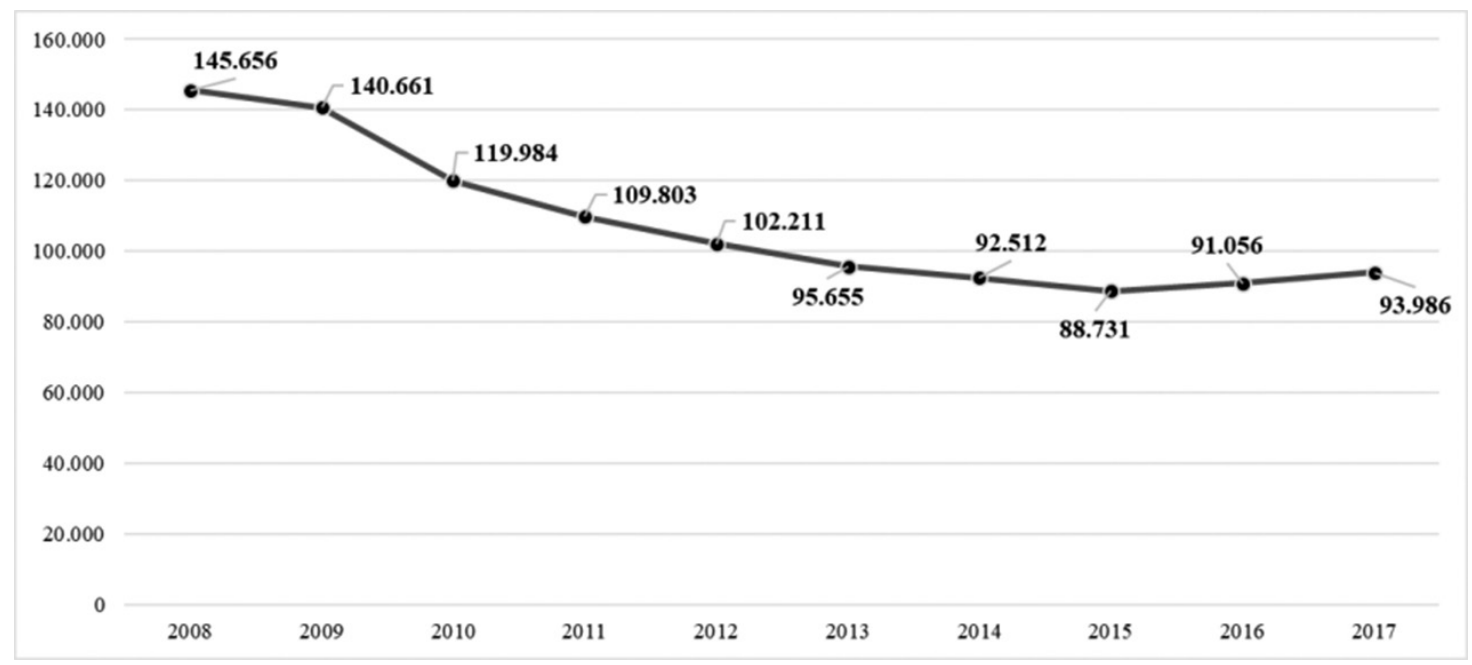

Fig. 1: Total number of workers employed in the Croatian construction sector (2008-2017). Source: Croatian Bureau of Statistics 2018a; processing by authors. 
semiskilled, skilled, and highly skilled employees in the Croatian construction sector has been decreasing continuously since 2011. However, the number of unskilled employees has grown by $8 \%$ in the 2015-2017 period, while between 2016 and 2017, the number of employees of any other skill level decreased. This indicates the need for a more detailed analysis of worker skill levels, which is further reported in the form of longitudinal data on the percentage of each skill level among the total number of construction employees.

To evaluate the percentages of the different skill levels, previously established methodology (Clarke and Herrmann 2007) was followed. This methodology was also used in previous research (Ceric et al. 2009) to determine the characteristics of the Croatian educational structure. Ceric et al. (2009) concluded that the Croatian labor market during the 1978-2008 period had trends similar to those of the German market. Some of them include the following:

- a decrease in the percentage of unskilled employees; and

- an increase in the percentage of skilled and formally educated employees.

A decrease in the unskilled and an increase in the number of skilled and formally educated workers are the result of changes in the technological, organizational, and managerial aspects of construction in recent years. Clarke and Herrmann (2007) indicate that this type of workers' educational structure, along with Germany's programs of dual vocational training, planned education, and labor market planning, is the main reason for the on-site productivity rates of German labor being higher than the corresponding British rates.

However, the analysis of Croatian construction workers' educational structure in the 2008-2017 period (shown in Figures 2 and 3) revealed some abnormalities in the above-mentioned trends. New data show that in the 2015-2017 period, the educational structure followed different trends:

- an increase in the percentage of unskilled employees; - a decrease in the percentage of skilled employees;

- an increase in the percentage of employees with secondary school education;

- a stagnation in the percentage of employees with basic school and nonuniversity degree; and

- a decrease in the percentage of employees with university degree.

For the purpose of this analysis, all semiskilled, skilled, and highly skilled employees are called "skilled". Their percentage was decreasing in the whole period spanning 2008-2017. Some of the formally educated employees with high school education replaced them, but the lack of skills is clearly a problem for the Croatian construction industry. Although the percentage of formally educated employees increased when considering the total, the percentage of unskilled employees also increased in the 2015-2017 period, which indicates the abnormality in established trends. The decrease in the percentage of

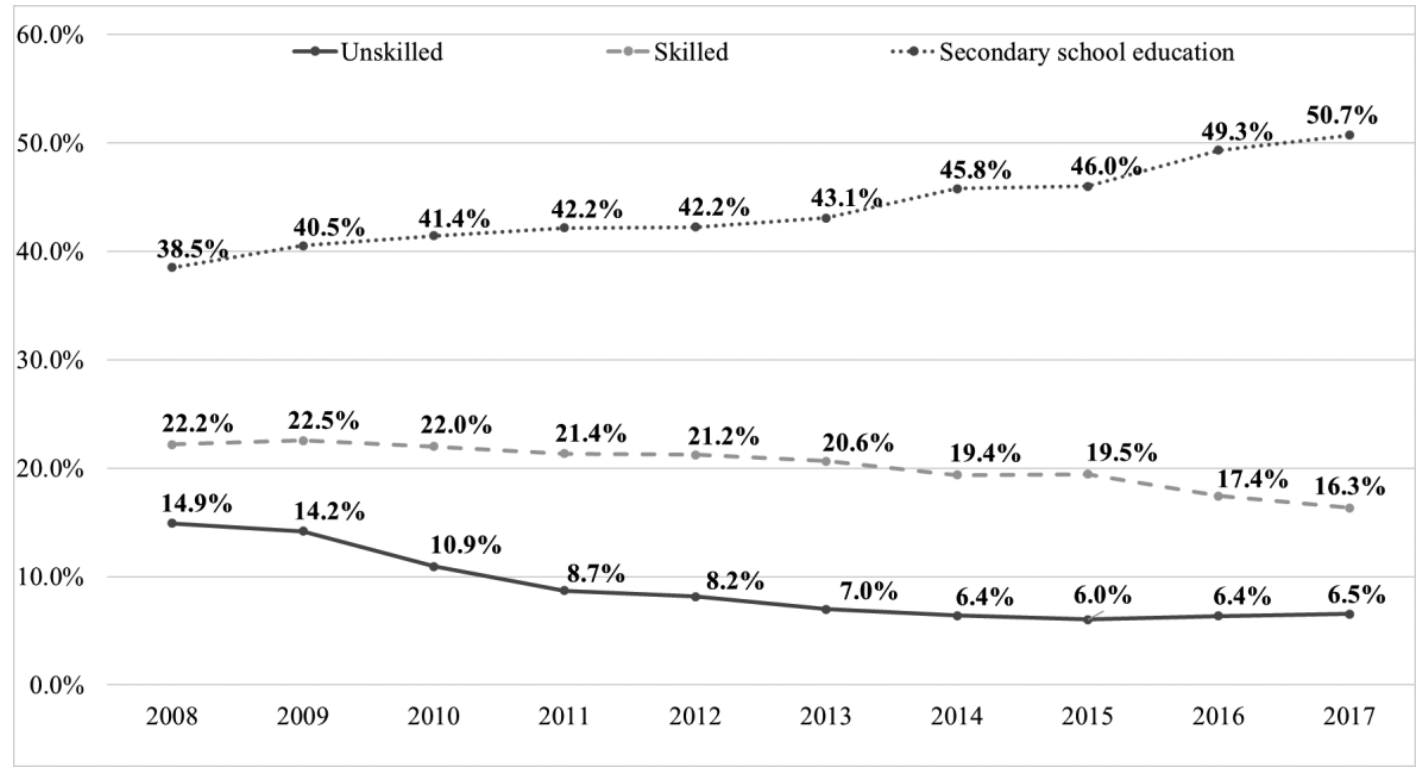

Fig. 2: Percentage of employees of different skill levels in the Croatian construction sector (2008-2017): unskilled, skilled, and secondary school education. Source: Croatian Bureau of Statistics 2018a; processing by authors. 


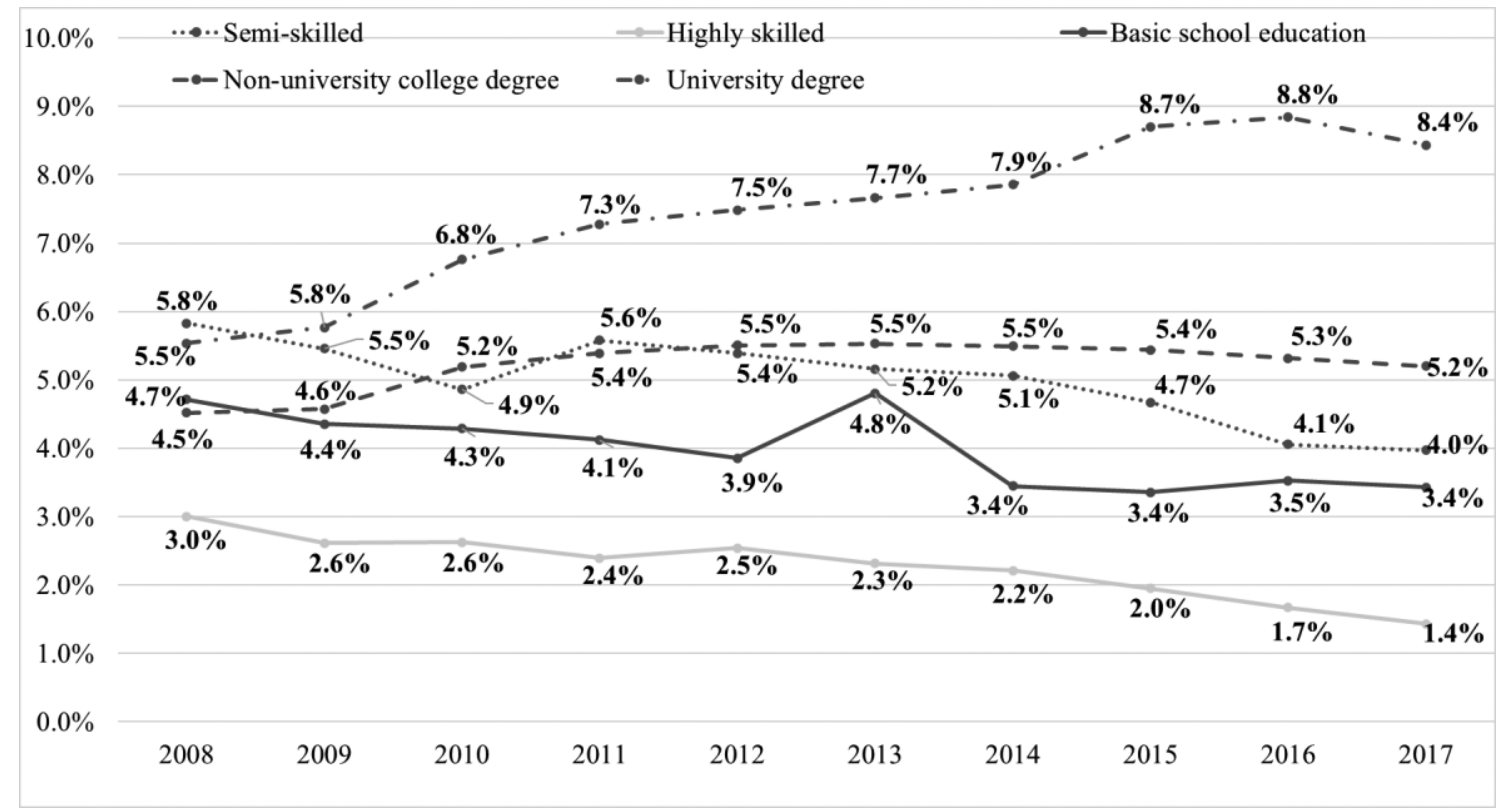

Fig. 3: Percentage of employees of different skill levels in the Croatian construction sector by educational attainment (2008-2017): semiskilled, highly skilled, basic school education, nonuniversity degree, and university degree. Source: Croatian Bureau of Statistics 2018a; processing by authors.

highly educated employees (with nonuniversity and university degrees) is also concerning.

This analysis has its limitations as different methods are used to collect data on the total number of workers employed and on the number of workers by educational employment. For example, in 2017, the qualifications of 31,024 workers employed in the construction sector were unknown to the Croatian Bureau of Statistics (2018a); thus, they were employed but not accounted for in terms of qualifications. Nevertheless, the findings of this analysis indicate a crisis in the Croatian construction labor market. Thus, the stabilization of trends in terms of the educational structure of labor is essential for the Croatian construction industry. A current increase in the percentage of unskilled workers will result in poor quality, low productivity, and late project completion, as argued in the "Literature review" section. Therefore, the Croatian construction sector needs to develop appropriate response strategies in order to attract more skilled and highly educated employees.

\subsection{Existing measures in Croatia}

The Croatian Employment Service is actively working on measures for the retention of existing workers. One of the effective measures implemented by the Croatian Employment Service has been the retraining of unemployed people. Retraining enables unemployed people to change their professions with the help of financing from the Croatian Employment Service (2015).

In addition, the Government of the Republic of Croatia is working on measures to attract new foreign employees. Annual quotas for the employment of foreign workers have been increasing year over year. Figure 4 shows the number of authorized permits for foreign workers in the construction sector. In the period spanning 20162020, the number increased from 500 to 33,300 permits, which represents $42 \%$ of the total number of authorized permits in 2020. The most sought-after construction professionals are carpenters (5000 permits), masons (5000 permits), unskilled construction workers (2800 permits), assemblers (2800 permits), steel-benders (2500 permits), concrete workers (2000 permits), and plasterers (1500 permits). Data show that Croatia lacks a large number of skilled workers, as well as unskilled workers to a smaller extent. The employment of foreign workers can be a shortterm measure for mitigating the labor shortage in Croatia, but, in that case, specific HRM strategies need to be implemented by construction companies. In fact, different cultural characteristics and possible skill mismatches are to be expected when employing foreign workers.

The Croatian Chamber of Economy supported the measure of employment of foreign workers in their recent report (Croatian Chamber of Economy 2017). Nevertheless, they emphasized that this is only a short-term, "fire-fighting” measure. They further appealed for changes in the education system as the only possible long-term solution 


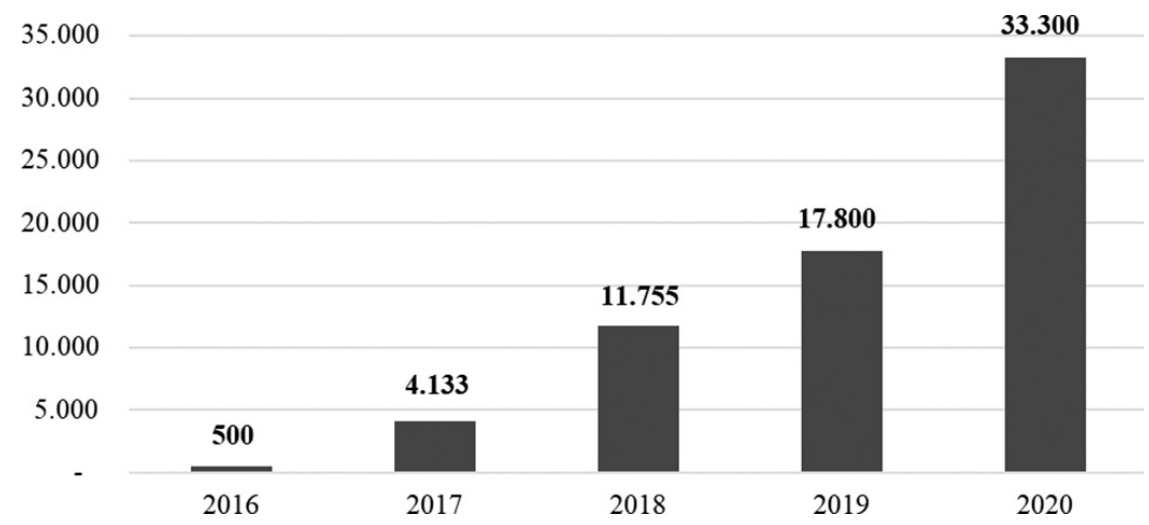

Fig. 4: Annual quotas for employment of foreign workers in the Croatian construction sector (2016-2020). Source: Official Gazette, 2016-2019; processing by authors.

for the labor shortage in construction. They also mention dual vocational education and retraining as valuable mitigation measures. Dual vocational education has, in fact, been advocated by the Croatian Ministry of Science and Education through the adoption of two documents: Model of Croatian Dual Education (Croatian Ministry of Science and Education 2018a); and Experimental Program: "Dual Education" (Croatian Ministry of Science and Education 2018b). The experimental program is planned for implementation in the 2018-2019 and 2019-2020 academic years. Dual education is characterized by the direct involvement of employers in the academic system. Students learn both in educational institutions and in the workplace. The result is a more-effective learning process and partial fulfillment of labor market demands by employing young and motivated workers.

Another important aspect to attracting new entrants to the construction labor market is a change in the construction sector's poor image. To this end, construction workers' rights are being protected by a Trade Union in the construction industry in Croatia. The Trade Union and the Construction Employers' Association have established collective bargaining agreements for the construction industry to implement better working conditions and increases in the wages of construction workers. The Union and the Construction Employers' Association believe that increases in wages are essential for attracting new employees into the market (Varosanec 2019).

\subsection{Discussion on possible response strategies}

To improve the current labor market crisis in Croatia, a set of appropriate response strategies is suggested. They are based on the current measures proposed by the State and an analysis of other countries with similar problems. They are listed in Table 1, along with the main actors of the Croatian construction industry enrolled in each strategy.

The strategies in Table 1 are divided according to two identified issues in Croatia: labor shortage; and skill shortage. In both cases, there are short-term and long-term strategies that need to be addressed. As a short-term solution for the labor shortage, the existing measure of employment of foreign workers should be enhanced. The government will be obligated to increase the annual quotas, and employers will have to provide additional training to foreigners, as well as existing workers, in terms of development of multiskilling. Other identified strategies, such as labor sharing and contracting less work, are both inappropriate for the current market situation. In the period of increase in volume indices of construction work, construction companies cannot afford this type of measures, but these can be applicable in a situation in which the construction indicators start to decrease. Nevertheless, to provide a long-term answer for the labor shortage, the Construction Trade Union and the Construction Employers' Association should be included in strategies aimed at better promoting the construction profession and changing the image of the construction sector. Together with the employers, these two associations can be involved in the organization of construction career fairs, school-to-work programs, and construction weeks (or similar events) in order to encourage the entry of new workers on the market. They can also provide support to construction companies in implementing better HRM practices, which should include material and nonmaterial compensation. Better relations between organizations and their employees will, in the long term, change the current poor image of the construction industry. To minimize the need for labor at the construction sites, employers could initiate the redesigning of construction processes. Nevertheless, new technology and 
Tab. 1: Response strategies for labor and skill shortages, as well as the main actors in the Croatian construction industry

\begin{tabular}{|c|c|c|c|}
\hline & & Response strategy & Actors \\
\hline \multirow[t]{6}{*}{$\begin{array}{l}\text { Labor } \\
\text { shortage }\end{array}$} & \multirow[t]{3}{*}{ Short term } & $\begin{array}{l}\text { Enhancement of annual quotas for employment of foreign } \\
\text { workers }\end{array}$ & Government \\
\hline & & Employment of foreign workers & Employers \\
\hline & & $\begin{array}{l}\text { Additional training of employed skilled workers and imple- } \\
\text { mentation of multiskilling on construction sites }\end{array}$ & Employers \\
\hline & \multirow[t]{3}{*}{ Long term } & $\begin{array}{l}\text { Better promotion of construction profession and changing the } \\
\text { image of the construction sector }\end{array}$ & $\begin{array}{l}\text { Trade Union; Construction Employers' } \\
\text { Association; employers }\end{array}$ \\
\hline & & Improvement of HRM practices (material and nonmaterial & Trade Union; Construction Employers' \\
\hline & & $\begin{array}{l}\text { Redesigning the construction processes, the implementation } \\
\text { of new technology and techniques, prefabrication, and auto- } \\
\text { mation of construction sites }\end{array}$ & Employers \\
\hline \multirow{5}{*}{$\begin{array}{l}\text { Skill } \\
\text { shortage }\end{array}$} & Short term & Retraining the long-term unemployed & Croatian Employment Service \\
\hline & \multirow[t]{4}{*}{ Long term } & Construction labor market planning & $\begin{array}{l}\text { Government; Croatian Ministry of Science } \\
\text { and Education; Trade Union; Construction } \\
\text { Employers' Association; employers }\end{array}$ \\
\hline & & Implementation of construction skill certification scheme & $\begin{array}{l}\text { Government; Trade Union; Construction } \\
\text { Employers' Association }\end{array}$ \\
\hline & & $\begin{array}{l}\text { Changes and improvements in formal education: vocational, } \\
\text { undergraduate, and graduate education }\end{array}$ & $\begin{array}{l}\text { Croatian Ministry of Science and Educa- } \\
\text { tion }\end{array}$ \\
\hline & & $\begin{array}{l}\text { Improvements in informal (on-the-job) skill formation training } \\
\text { on construction sites }\end{array}$ & Employers \\
\hline
\end{tabular}

techniques, prefabrication, and automation may minimize the need for labor, but these interventions require operatives to receive continual retraining, which also consumes time and money (MacKenzie et al. 2000).

For the problem of skill shortages in the Croatian construction industry, one existing short-term strategy is recognized. Organized by the Croatian Employment Service, retraining of the long-term unemployed can quickly fill some of the current skill shortages on construction sites. However, the current lack of inclusion of employers in the education system has led to an insufficient number of skilled employees in the industry. In this regard, labor market planning and construction skill certification could bring about cooperation between all the participants and provide valuable long-term strategies for minimizing the skill shortages. The Construction Employers' Association can become the association responsible for collecting, analyzing, and disseminating skill-related data within the country. Thus, employers could plan more effectively for the future, Government could provide support in terms of legislative requirements, and the Croatian Ministry of Science and Education could define realistic quotas for students' enrollment in specific educational programs. Furthermore, construction skill certification can provide a voluntary register of the skills, competence, and qualifications of individual workers within the industry
(MacKenzie et al. 2000). In the UK and Germany, this measure already provides benefits for construction organizations in terms of recruitment of the right people, and it is recognized as one of the successful strategies for mitigating skill shortages (MacKenzie et al. 2000). In terms of education, changes should be implemented in undergraduate and graduate educational programs, as well as in vocational education. Efforts have already been made by the Croatian Ministry of Science and Education to start a new dual vocational education program in Croatia, following the model well established and verified in Germany. Together, these educational strategies should encourage more young people to enter the industry and develop their skills. Along with formal education, employers can provide informal, on-the-job training and, therefore, develop skills depending on their needs.

\section{Conclusions}

Considering the current global growth in the construction industry, the lack of qualified workers has become a serious issue all over the world. Researchers have been warning about skilled labor shortages for decades, but no scientific answer has been given in the discussions on this subject. The conclusions in previous research highlight 
the shortage of skilled construction labor as a global problem. By answering the six research questions, this paper provides important insight into the causes of labor shortages and the response strategies for the minimization of the same across the industry.

In this paper, statistical data collected from the Croatian Bureau of Statistics are used to investigate the scale of the construction labor and skill shortages in Croatia. The contributions of this analysis are the verification of the global shortage of skilled labor identified in other research and the discovery of two adverse trends in the Croatian construction labor market, namely, an increase in the number of unskilled workers and a decrease in the numbers of workers with other educational attainment. As argued earlier, these trends result in poor quality, low productivity, and late project completion. Their stabilization is essential for the success of the Croatian construction industry. Appropriate response strategies for the construction labor market crisis in Croatia are suggested based on literature analysis and knowledge of the current characteristics of the Croatian construction sector. The main actors enrolled in each strategy, which involves government bodies, professional associations, trade unions, and employers, are also identified and commented on.

In addition, this paper proposes the methodology for labor market analysis, which can be used by other researchers while investigating similar issues in other countries. The limitations of the analysis arise from the different methodologies used in the collection of the data on the total number of workers employed and on the number of workers by educational attainment. For this reason, future research should concentrate on the unification of such data and a more detailed analysis to uncover the real extent of the problem. Nevertheless, the collection of causes of and response strategies for improving the labor shortages in the construction industry also provides a valuable ground for future research, as the verification of the suggested strategies is needed for the industry as a whole.

\section{References}

Abiola, R. O. (2004). Productivity improvement in project organization. Journal of the Nigerian Institute of Quantity Surveyors, 46(5), pp. 17-22.

AGC of America. (2018). Worker Shortage Survey Analysis. Available at https://www.agc.org/sites/default/files/2018_Worker_ Shortage_Survey_Analysis.pdf (accessed 5 February, 2019).

Aiyetan, O. A., \& Dillip, D. (2018). System dynamics approach to mitigating skilled labour shortages in the construction industry: A South African context. Construction Economics and Building, 18(4), pp. 45-63.

Bilau, A. A., Ajagbe, M. A., Kigbu, H. H., \& Sholanke, A. B. (2015). Review of shortage of skilled craftsmen in small and medium construction in Nigeria. Journal of Environment and Earth Science, 5(15), pp. 98-110.

Buturac, G. (2013-2018). Gradevinarstvo i nekretnine. Sektorske analize, Available at https://www.eizg.hr/vijesti/ publikacije-70/novi-broj-sektorskih-analiza-gradjevinarstvo-i-nekretnine/4362 (accessed 18 February, 2019).

Ceric, A., Antic, M., \& Lazic, M. (2009). Changes in qualification structure of labour in construction in Croatia (1978 - 2008). In: Ceric, A., \& Radujkovic, M. (eds.), CIB Joint International Symposium 2009, Dubrovnik, September 27-30, pp. 577-582.

Chan, P. W., \& Dainty, A. R. J. (2007). Resolving the UK construction skills crisis: A critical perspective on the research and policy agenda. Construction Management and Economics, 25(4), pp. 375-386.

Chini, A. R., Brown, B. H., \& Drummond, E. G. (1999). Causes of the construction skilled labor shortage and proposed solutions. In: 35th Associated Schools of Construction (ASC) Annual International Conference Proceedings, California Polytechnic State University - San Luis Obispo, California, April 7-10.

Clarke, L., \& Herrmann, G. (2007). Divergent divisions of construction labour: Britain and Germany. In: Dainty, A., Green, S., \& Bagilhole, B. (eds.), People and Culture in Construction A Reader. Taylor \& Francis, London, UK.

Croatian Bureau of Statistics. (2018a). Statistical Yearbooks of the Republic of Croatia. Available at https://www.dzs.hr/Hrv/ Publication/stat_year.htm (accessed 18 February, 2019).

Croatian Bureau of Statistics. (2018b). Migration of Population of Republic of Croatia, 2017. Available at https://www.dzs.hr/ Hrv_Eng/publication/2018/07-01-02_01_2018.htm (accessed 19 February, 2019).

Croatian Chamber of Economy. (2017). HGK podrzava nove kvote za strance. Available at https://www.hgk.hr/hgk-podrzavanove-kvote-za-strance (accessed 21 February, 2019).

Croatian Employment Service. (2015). Projects of the Hrvatski zavod za zaposljavanje. Available at http://staro.hzz.hr/default. aspx?id=18014 (accessed 21 February, 2019).

Croatian Ministry of Science and Education. (2018a). Model of Croatian Dual Education. Available at https://mzo.hr/ sites/default/files/dokumenti/2018/OBRAZOVANJE/ Strukovne-Dualno/model_hrvatskoga_dualnog_obrazovanja. pdf (accessed 21 February, 2019).

Croatian Ministry of Science and Education. (2018b). Experimental Program: "Dual Education". Available at https://mzo. $\mathrm{hr} /$ sites/default/files/dokumenti/2018/OBRAZOVANJE/ Strukovne-Dualno/eksperimentalni_program_dualno_ obrazovanje_.pdf (accessed 21 February, 2019).

Dainty, A. R. J., \& Bagilhole, B. M. (2005). Equality and diversity in construction: Guest editorial. Construction Management and Economics, 23(10), pp. 995-1000.

Dainty, A., Green, S., \& Bagilhole, B. (2007). People and culture in construction - contexts and challenges. In: Dainty, A., Green, S., \& Bagilhole, B. (eds.), People and Culture in ConstructionA Reader, Taylor \& Francis, London, UK, pp. 3-25.

Dainty, A. R. J., Ison, S. G., \& Root, D. S. (2004). Bridging the skills gap: A regionally driven strategy for resolving the construction labour market crisis. Engineering, Construction and Architectural Management, 11(4), pp. 275-283. 
Debrah, Y. A., \& Ofori, G. (1997). Flexibility, labour subcontracting and HRM in the construction industry in Singapore: Can the system be refined? International Journal of Human Resource Management, 8(5), pp. 690-709.

Debrah, Y. A., \& Ofori, G. (2001). The State, skill formation and productivity enhancement in the construction industry: The case of Singapore. International Journal of Human Resource Management, 12(2), pp. 184-202.

Djukan, P., Dusek, A., Pavlin, Z., Percel, D., Petkovic, A., Pletikapic, Z., et al. (2015). Hrvatsko graditeljstvo - novi pocetak: Prijedlog za razmisljanje i djelovanje, Hrvatska komora inzenjera gradevinarstva, Zagreb.

EU SME Centre. (2015). Sector Report: The Construction Sector in China, EU SME Centre, Beijing.

European Commission. (2015). Determining Labour Shortages and the Need for Labour Migration from Third Countries in the EU, Synthesis Report for the EMN Focussed Study 2015. European Commission, Brussels, Belgium.

European Commission. (2017). European Construction Sector Observatory: Analytical Report: Improving the Human Capital Basis. European Commission, Brussels.

Eurostat. (2019). Annual detailed enterprise statistics for construction (NACE Rev. 2, F). Available at https://ec.europa. eu/eurostat/en/web/products-datasets/-/SBS_NA_CON_R2 (accessed 5 February, 2019).

Farmer, M. (2016). The Farmer Review of the UK Construction Labour Model: Modernise or Die. Construction Leadership Council (CLC), London.

Fiori, C. M. (2003). What's wrong with working in construction? How image and diversity issues are affecting the shortage of skilled labor. In: Molenaar, K. R., \& Chinowsky, P. S. (eds.), Proceedings of the 2003 Construction Research Congress, Honolulu, Hawaii, March 19-21, American Society of Civil Engineers (ASCE).

Ford, C., \& MacKenzie, R. (2007). Concrete solutions? - Recruitment difficulties and casualization in the UK construction industry. In: Dainty, A., Green, S., \& Bagilhole, B. (eds.), People and Culture in Construction - A Reader. Taylor \& Francis, London, UK, pp. 26-38.

Gomar, J. E., Haas, C. T., \& Morton, D. P. (2002). Assignment and allocation optimization of partially multiskilled workforce. Journal of Construction Engineering and Management, 128(2), pp. 103-109.

Glavinja, D., Ceric, A., \& Nahod, M. M. (2017). Corruption in the construction industry: Comparison of survey results in Croatia and the United Kingdom. International Research Conference 2017: Shaping Tomorrow's Built Environment, Salford, pp. 34-44.

Haas, C. T., Rodriguez, A. M., Glover, R., \& Goodrum, P. M. (2001). Implementing a multiskilled workforce. Construction Management and Economics, 19(6), pp. 633-641.

Han, S. H., Park, A. H., Jin, E. J., Kim, H., \& Seong, Y. K. (2008). Critical issues and possible solutions for motivating foreign construction workers. Journal of Management in Engineering, 24(4), pp. 217-226.

International Labour Organization. (2020). World Employment and Social Outlook Trends 2020. International Labour Office, Geneva.

Karimi, H., Taylor, T. R. B., Dadi, G. B., Goodrum, P. M., \& Srinivasan, C. (2018). Impact of skilled labor availability on construction project cost performance. Journal of Construction Engineering and Management, 144(17), 04018057.

Kashiwagi, D. T., \& Massner, S. (2002). Solving the construction craftperson skill shortage problem through construction undergraduate and graduate education. In: Berryman, C. W. (ed.), 38th Associated Schools of Construction (ASC) Annual International Conference Proceedings, Virginia Polytechnic Institute and State University - Blacksburg, Virginia, April 11-13.

Kim, S., Chang, S., \& Castro-Lacouture, D. (2020). Dynamic modeling for analyzing impacts of skilled labor shortage on construction project management. Journal of Management in Engineering, 36(1), 04019035.

Lyu, S., Hon, C. K. H., Chan, A. P. C., Wong, F. K. W., \& Javed, A. A. (2018). Relationships among safety climate, safety behavior, and safety outcomes for ethnic minority construction workers. International Journal of Environmental Research and Public Health, 15(3), p. 484.

MacKenzie, S., Kilpatrick, A. R., \& Akintoye, A. (2000). UK construction skills shortage response strategies and an analysis of industry perceptions. Construction Management and Economics, 18(7), pp. 853-862.

McGuinness, S., \& Bennett, J. (2006). Examining the link between skill shortages, training composition and productivity levels in the construction industry: Evidence from Northern Ireland. The International Journal of Human Resource Management, 17(2), pp. 265-279.

Mills, A. J., Eurepos, G., \& Wiebe, E. (eds.) (2010). Encyclopedia of case study research. Sage, Thousand Oaks.

Morello, A., \& Issa, R. R. A. (2018). Exploratory study of recruitment and retention of women in the construction industry. Journal of Professional Issues in Engineering Education and Practice, 144(2), 04018001.

Official Gazette. (2016-2019). Odluka o utvrdivanju godisnje kvote dozvola za zaposljavanje stranaca za kalendarsku godinu: 2016. (NN 039/2016.), 2017. (NN 074/2017.), 2018. (NN 071/2018.), 2019. (NN 116/2018.), 2020. (NN 113/2019).

Olsen, D., Tatum, M., \& Defnall, C. (2012). How industrial contractors are handling skilled labor shortages in the United States. In: Sulbaran, T. (ed.), 48th Associated Schools of Construction (ASC) Annual International Conference Proceedings, Birmingham City University, Birmingham, UK, April 11-12.

Oseghale, B. O., Abiola-Falemu, J. O., \& Oseghale, G. E. (2015). An evaluation of skilled labour shortage in selected construction firms in Edo state, Nigeria. American Journal of Engineering Research, 4(1), pp. 156-167.

Pan, W., Chen, L., \& Zhan, W. (2020). Implications of construction vocational education and training for regional competitiveness: Case study of Singapore and Hong Kong. Journal of Management in Engineering, 36(2), 05019010.

Pokos, N. (2017). Osnovna demografska obiljezja suvremenog iseljavanja iz Hrvatske. Politicke analize, 31, pp. 16-23.

Powell, A., \& Sang, K. J. C. (2013). Equality, diversity and inclusion in the construction industry: Editorial. Construction Management and Economics, 31(8), pp. 795-801.

Raiden, A., Pye, M., \& Cullinane, J. (2007). The nature of the employment relationship in the UK construction industry - A flexible construct? In: Dainty, A., Green, S., \& Bagilhole, B. (eds.), People and Culture in Construction - A Reader. Taylor \& Francis, London, UK, pp. 39-55. 
Sandrk Nukic, I., \& Huemann, M. (2016). Organizational culture of the Croatian construction industry. Engineering, Construction and Architectural Management, 23(2), pp. 237-260.

US Census Bureau. (2018). Construction spending: Historical value put in place. Available at https://www.census.gov/ construction/c30/historical_data.html (accessed 5 February, 2019).

Varosanec, S. (2019). Kontrola placa iz kolektivnog ugovora uvjet za rast osnovne place na 4500 do 5000 kuna. Poslovni dnevnik, Available at http://www.poslovni.hr/hrvatska/ kontrola-placa-iz-kolektivnog-ugovora-uvjet-za-rast-osnovne-place-na-4500-do-5000-kuna-349620?fbclid=IwAR1mq0DRIl50794POgv60J8IUj9dYaA7rZJHjwK5fHI2MkktMCieNPdQe7c (accessed 22 February, 2019).

Wang, Y., Goodrum, P. M., Haas, C. T., \& Glover, R. W. (2008). Craft training issues in American industrial and commercial construction. Journal of Construction Engineering and Management, 134(10), pp. 795-803.

Yin, R. K. (2018). Case Study Research and Applications: Design and Methods, 6th edn. Sage, Los Angeles. 